B. М. Махінов

\title{
ЛІНГВОДИДАКТИЧНА ШКОЛА «МОВИ Й МОВЛЕННЯ» Ф. ДЕ СОССЮРА ПРО ФОРМУВАННЯ МОВНОЇ ОСОБИСТОСТІ
}

Махінов В. М. Лінгводидактична школа «мови й мовлення» Ф. де Соссюра про формування мовної особистості.

Стаття присвячена проблемі розвитку соціокультурних детермінантів формування мовної особистості на матеріалі школи «мови й мовлення» Ф. де Соссюра. Проаналізовано історичний розвиток соціокультурного компонента формування мовної особистості у контексті загального поняття мовленнєвої діяльності, складниками якої $є$ мова й мовлення.

Ключові слова: міжкультурна комунікація, школа «мови й мовлення» Ф. де Соссюра, соціокультурний компонент мовної особи, формування мовної особистості, загальноєвропейський освітній простір.

Махинов В. Н. Лингводидактическая школа «язык и речь» Ф. де Соссюра о формировании языковой личности.

Статья посвящается проблеме развития социокультурных детерминантов формирования языковой личности на материале школы «язык и речь» Ф. де Соссюра. Анализируется историческое развитие социокультурного компонента формирования языковой личности в контексте общего понятия речевой деятельности, составляющими которой являются язык и речь.

Ключевые слова: межкультурная коммуникация, школа «язык и речь»

С В. М. Махінов, 2015. 
Ф. де Соссюра, социокультурный компонент языковой личности, формирование языковой личности общеевропейское образовательное пространство.

Makhinov V. M. Linguodidactic School «Language and Speech» of F. de Saussure on the Formation of Language Identity.

The article is sanctified to the problem of development of sociocultural determinants of forming of language personality on material of school of «language and speech « of F. De Saussure. Historical development of sociocultural component of forming of language personality is analyzed in the context of general concept of speech activity the constituents of that are a language.

Key words: cross-cultural communication, school of «language and speech» of F. de Saussure sociocultural component of language personality, forming of language personality, European educational space.

Сучасна Європа являє собою досить складне культурне утворення, що виникло внаслідок накладання один на одного кількох шарів культурної ідентичності, до яких належать економічна, політична ідентичність тощо, а також ідентичність на рівні літератури, кіно, інших проявів духовної культури. Навчання іноземних мов на сучасному етапі розглядається не тільки як педагогічна чи методична проблема, а як створення умов для усвідомлення відмінностей у рідній та іншомовній культурі, виховання толерантного ставлення до представників інших народів, зниження рівня етноцентризму, формування навичок іншомовної міжкультурної комунікації та готовності до діалогу культур.

Сьогодні перед педагогічною наукою і школою України гостро стоїть питання реформування освіти в напрямі гуманізації навчання, передусім, визначення соціокультурних детермінантів формування мовної особистості. Одним зі шляхів підвищення ефективності викладання іноземних мов у вищій школі $\epsilon$ використання соціокультурного фактору.

Мета статті - визначити тенденції теорії і практики формування мовної особистості в європейському освітньому просторі кінця XIX початку XX ст. на матеріалі школи «мови й мовлення» Ф. де Соссюра. У більшості європейських країн цей компонент визнано істотною частиною змісту навчання будь-якої іноземної мови. Але в Україні до сьогодні він і досі належно не висвітлений у педагогічному та загальнометодичному аспектах.

Як педагогічна i соціокультурна проблема мовні стратегіï 
формування мовної особистості стали предметом дослідження порівняно недавно. Практично вона розробляється в останні два - три десятиріччя. У iï основі знаходяться фундаментальні дослідження феномена мови знаменитих мовознавців (від О. Потебні до Я. Білодіда), а також дослідників мовно-педагогічних і виховних технологій (від Я. А. Коменського до А. Макаренка, Г. Ващенка і В. Сухомлинського) [2, с. 71]. Видатні досягнення названих вчених $\epsilon$ першим і основним пластом літератури, на якій вибудовувалось наше дослідження.

Серед робіт сучасних науковців, які тією чи тією мірою торкалися досліджуваної нами проблеми, ми виділяємо три відносно самостійні групи наукових розробок [4].

Перша 3 них присвячена дослідженню загальнокультурної ситуації, що склалася в Європі в післявоєнний період, особливо після розпаду СРСР і руйнації «соціалістичного табору» (С. Веселовський, М. Білоусов, І. Бураківський, Л. Гайдуков, Л. Губерський, С. Годун, А. Дугін, В. Копійка, В. Крушинський, В. Манжола, І. Мінгазутдінов, Г. Немиря, О. Павлюк, Д. Сіджанскі, М. Срежньова).

Другу групу досліджень складають роботи вчених, які намагалися проникнути в архітектоніку європейського діалогу, зумовлену розмаїттям культур i ментальних характеристик народів європейського простору (3. Бзежинський. Б. Гуменюк, А. Зленко, В. Литвин, М. Михальченко, Г. Руденко та ін.) [4, с. 7].

До третьої групи ми відносимо дослідження авторів, мовні стратегії в яких є предметом безпосереднього теоретичного аналізу. У цьому плані мовні стратегії вивчаються представниками багатьох наук - філологами i лінгвістами, психологами i семіотиками, філософами i, навіть, математиками. Серед науковців філологічного та літературного профілю, праці яких мають знаковий характер, слід насамперед назвати А. Грищенка, М. Жулинського, Л. Мацько, А. Міщенка, В. Німчука, В. Яременка; серед філософів В. Андрущенка, К. Жоля, М. Михальченка, Б. Парахонського та ін. $[3$, с. 17].

Фердинанд де Соссюр (1857 - 1913) - один з видатних лінгвістів свого часу, сформулював тенденції теорії і практики формування мовної особистості в європейському освітньому просторі кінця XIX початку XX ст. Він народився в Женеві в родині вчених. У 1875 році 
Соссюр почав навчання в Женевському університеті, а з 1876 року навчався в Лейпцизі, де слухав лекції Лескіна, Остгофа, Бругмана. У 1879 р. він надрукував відому книгу «Трактат про первісну систему голосних в індоєвропейських мовах». У 1878-1879 навчальному році Соссюр навчається в Берлінському університеті. Наприкінці 1879 р. він повернувся до Лейпцига і в лютому 1880 р. захистив докторську дисертацію «Родовий абсолютний у санскриті». У наступні роки Соссюр читає лекції в Парижі, де в нього навчалися Л. Майє (18661936), М. Граммон (1866-1946). 1891 року він повертається до Женевського університету, де згодом став професором санскриту й порівняльної граматики індоєвропейських мов. У 1906 р. Соссюр отримав кафедру загального мовознавства. У 1906-1911 р. тричі прочитав курс загального мовознавства, який слухали Ш. Баллі (18651947) та А. Сеше (1870-1946). Прочитані Соссюром курси iз загального мовознавства були після його смерті видані за записами лекцій Ш. Баллі та А. Сеше в 1916 р. під назвою «Курс загальної лінгвістики». 1933 року в Москві було видано російський переклад. Ця книга стала всесвітньовідомою своєю оригінальною концепцією і вплинула на становлення різних напрямків лінгвістики XX ст.

Проблеми, поставлені й розглянуті Ф. де Соссюром у «Курсі загальної лінгвістики», - мова й мовлення, соціокультурні детермінанти формування мовної особистості, системність мови, іiі знаковий характер, синхронія й діахронія й внутрішня лінгвістика $[5$, c. 71] - уже багато в чому були сформульовані його попередниками й сучасниками: В. фон Гумбольдтом, Бодуеном де Куртене, М. Крушевським, В. Уїтні та іншими мовознавцями. Проте заслуга Соссюра полягає в тому, що він, поєднавши ці проблеми, створив загальну теорію мови, хоч багато в чому суперечливу й позбавлену остаточного розв'язання всіх питань. Основним методом побудови лінгвістичної теорії Соссюр обрав метод антиномій, який широко використовував В. Фон Гумбольдт та інші лінгвісти ХІХ ст. (наприклад, французький лінгвіст В. Анрі видав 1986 року книгу «Лінгвістичні антиномії)).

Перша важлива антиномія концепції Соссюра - мова й мовлення, тенденції теорії і практики формування мовної особистості. Проблема ïx співвідношення вперше була поставлена Гумбольдтом, потім іiі розглядали Потебня й Бодуен де Куртене. Розв'язуючи цю проблему, 
Соссюр відштовхується від загального поняття мовленнєвої діяльності, складниками якої $\epsilon$ мова й мовлення [7, с. 171]. Мовленнєва діяльність дуже різноманітна, вона стосується й індивідуальної, і соціальної сфери, стикається $з$ такими царинами, як фізика, фізіологія, психологія, має зовнішній (звуковий) і внутрішній (психічний) бік. Мовленнєва діяльність - це властивість, притаманна людині. Мова й мовлення - це лише частини більш загального феномена, яким є мовленнєва діяльність. Мова й мовлення «тісно пов'язані між собою і взаємно передбачують одне: мова необхідна, щоб мовлення було зрозумілим й виконувало всі свої функції; мовлення, своєю чергою, необхідне для того, щоб встановилася мова: історично факт мовлення завжди передує мові».

Водночас мова й мовлення різняться між собою рядом ознак [7, с. 71-74]. Перша відмінність між ними полягає в тому, що мова соціальна, а мовлення індивідуальне. Мова - соціальний елемент мовленнєвої діяльності мовної особистості, зовнішній відносно індивіда. Він не може ані створювати мову, ані змінювати іiі. Мова як соціальний продукт засвоюється кожним індивідом уже в готовому вигляді. Визнаючи соціальний характер мови при формуванні мовної особистості, Соссюр наголошує на ії психологічній природі: мова - це сукупність асоціацій, наявних у мозку й скріплених колективною домовленістю. На відміну від мови, мовлення завжди індивідуальне, воно $\epsilon$ «індивідуальним актом волевияву й розуміння». У мовленні немає нічого колективного, його прояви - індивідуальні й миттєві.

По-друге, мова протиставляється мовленню як потенція його реалізації при формуванні мовної особистості. Мова потенційно існує в мозку індивіда у вигляді граматичної системи й словника. Реалізація цих потенційних можливостей відбувається в мовленні, у використанні засобів мови задля комунікації [7, с. 117].

По-третє, на відміну від нестійкості й одноразовості мовлення, мова стійка й довговічна. Мова відрізняється від мовлення, як «істотне від другорядного і більш-менш випадкового». Істотними є нормативні факти мови, закріплені мовною практикою, другорядні й випадкові коливання й індивідуальні відхилення в мовленні. Ураховуючи зазначені чинники, Соссюр вимагає окремо вивчати кожен бік мовленнєвої діяльності мовної особистості, пропонуючи розрізняти лінгвістику мови й лінгвістику мовлення, яка має другорядне 
значення [7, с. 121].

Протиставлення мови й мовлення Соссюр образно називає першим перехрестям на шляху формування мовної особистості. Другим перехрестям він називає антиномію синхроніі. Синхронія - це стан мови в даний час, статистичний аспект, мова в іiі системі. Діахронія - це еволюція мови, послідовність мовних фактів у часі, історичний або динамічний аспект. На думку Соссюра, «синхронічне - усе, що стосується статистичного аспекту» лінгвістики, «діахронічне - усе, що стосується еволюції». Звідси походить вимога виокремити нову пару незалежних дисциплін синхронічної та діахронічної лінгвістики. Синхронічна лінгвістика має вивчати логічні й психологічні відношення між наявними елементами мови, які утворюють їі систему, розглядаючи їх так, як вони сприймаються однією й тією самою колективною свідомістю при формуванні мовної особистості [7, с. 134]. Діахронічна лінгвістика має вивчати відношення, які пов'язують елементи мови в порядку послідовності; ці елементи «не сприймаються однією й тією самою колективною свідомістю», вони заміняються одні іншими, але не утворюють систему. Отже, синхронічна лінгвістика вивчає мову як систему, тобто має справу з мовою, а діахронічна досліджує мовлення мовної особистості, її об’єкт, і не утворює системи. Варто зазначити, що антиномію синхронії-діахронії розробляв ще Бодуен де Куртене, але як статику й динаміку мови.

Однією з основних заслуг Ф. де Соссюра вважають обгрунтування ним системного характеру мови та мовлення. Трохи раніше, ніж Соссюр, Б. де Куртене, роботи якого Соссюр високо цінував, запропонував розуміння системи мови як сукупності, частини якої пов'язані між собою різними відношеннями, що впливають на процес формування мовної особистості. У Соссюра система мови грунтується на протиставленні iі членів. Розглядаючи мову як систему математично точну, він користувався для позначення компонентів системи математичним терміном «член», уважаючи, що всі відношення в мові можуть бути виражені в математичних формулах. Мова як система формування мовної особистості характеризується двома особливостями: усі члени системи перебувають у рівновазі; система $\epsilon$ замкнутою [7, с. 147]. Система мови формується на підставі встановлення тотожностей i розбіжностей між іiі членами, тобто 
елементами системи. Соссюр наголошує на статичності як найважливішій ознаці мовної системи, хоч не розглядає іiі як цілком нерухомий стан системи. Визначальними в системі $\epsilon$ два типи відношень між іiі елементами - синтагматичні й асоціативні, заслуга у відкритті яких належить, на думку деяких дослідників, М. Крушевському. Синтагматичні відношення грунтуються на двох та більшій кількості членів відношення, «однаковою мірою наявних в актуальній послідовності». Синтагматичні відношення підпорядковуються принципу лінійності формування мовної особистості. Через дію цього принципу мовні одиниці «вишикуються» в лінію, де кожна одиниця утворює сполуку з сусідніми. Лінійні сполуки одиниць мови Соссюр називає синтагмами. Другий тип відношень він позначає як асоціативні, що безпосередньо впливають на процес формування мовної особистості, вони «поєднюють члени цього відношення у віртуальний мнемонічний (гр. Mneme - пам'ять) ряд» [7, с. 164]. В асоціативні відношення Соссюр залучає не лише морфологічні, але й смислові зв'язки між словами. На його думку, сукупність синтагматичних і асоціативних відношень «утворює мову й визначає ii функціонування». Мова представляє сукупність узаємопов'язаних елементів, де кожний член системи пов'язаний 3 іншими членами як у просторі (синтагматичні відношення), так і у свідомості мовця (асоціативні відношення).

Ф. де Соссюр обгрунтував знаковий характер мови. Учення про мову як систему знаків, які виражають поняття у свідомості мовця, посідає важливе місце в лінгвістичному доробку Соссюра. Він вважає мову системою знаків, «у якій істотним є лише поєднання значення й акустичного образу, причому обидва ці компоненти знака однаковою мірою психічні» [7, с. 171]. Мовний знак, за Соссюром, - це протиставлена двобічна психічна сутність мовної особистості: означення ( акустичний образ) й означуване (поняття). Мовні знаки це реальності, які знаходяться в мозку людини. Центральним знаком у механізмі мови є слово [7, с. 172]. Ф. де Соссюр пропонує створити нову науку про знаки взагалі - семіологію. Лінгвістика «як наука про особливі знаки» буде частиною семіології, iii найважливішим розділом, оскільки мова - це найскладніша й найпоширеніша семіологічна система». Соссюр зазначає характерні ознаки мовного знака, які безпосередньо впливають на процес формування мовної 
особистості. Це передусім довільність знака, тобто довільність, умовність зв'язку означення з означуваним у свідомості мовця. Проте, 3 іншого боку, цей знак є обов'язковим для мовного колективу, який ним користується, він соціально та соціокультурно зумовлений. Довільність знака зовсім не виключає його мотивованості, оскільки більшість слів у загальній системі мови мотивована. Принцип довільності знака породжує антиномію мінливість-немінливість знака. Немінливість мовних знаків характеризується тим, що люди вживають ï так, як встановлено традицією. У процесі історичного розвитку відношення між означенням й означуваним у знакові можуть змінюватися, тобто може змінитися звуковий склад слова, його значення або те й те разом, що тісно пов'язано 3 принципом безперервності соціокультурного та мовного розвитку [7, с. 175] .

Важливим для системного й знакового розуміння мови було наголошування Соссюром на значущості відмінностей у знаку й мові. Через те, що мовний знак - психічне явище, для нього важливі не матеріальні відмінності, а функціональні властивості. На його думку, у слові важливий не звук як такий, а ті звукові відмінності, які дають змогу мовцям відрізняти це слово від інших, «бо тільки ці звукові відмінності значущі» [7, с. 177]. У зв'язку з цим Соссюр розуміє фонему як сукупність розрізнювальних ознак, що потім було визнано Паризьким лінгвістичним гуртком.

Безпосередні учні Соссюра й ті мовознавці, на творчість яких він вплинув, не виявляють єдності в поглядах на знак та мову, оскільки багато положень його концепції суперечливі й допускають неоднозначне тлумачення. Послідовники Соссюра представлені трьома групами. Першу групу утворюють Ш. Баллі, А. Сеше, С. Карцевський (так звана Женевська школа), які дотримувалися концепції свого вчителя й розвивали його погляди. Мовознавці, які утворюють другу групу (А. Мейє, Ж. Вандрієс, Е. Бенвеніст, А. Соммерфельт), сприйняли соціологічні ідеї Соссюра, поєднавши їх 3 принципами порівняльно-історичного мовознавства. До третьої групи належать мовознавці різних відгалужень структуралізму. Передумов виникнення структуралізму кілька. Багато методологічних принципів, що впливають на процес формування мовної особистості, за своїм походженням, а іноді й за змістом, мають філософське забарвлення. Залежність від філософських течій далася взнаки й при 
виникненні структуральної лінгвістики як нового наукового напрямку. Переважно всі фундаментальні дослідження, які лежать в основі сучасного структуралізму, були проведені наприкінці XIX - початку $\mathrm{XX}$ ст. Бурхливе зростання природознавчих наук (відкриття періодичної системи хімічних елементів Менделеєва, закон Менделя про розщеплення спадкоємних ознак батьків та їх нащадків, відкриття Ч. Дарвіна тощо) увело в науку поняття дискретної структури матерії. Поняття фонеми й морфеми, уведене в цей період, якраз і виражало стосовно мови те, що відображали атоми, молекули стосовно хімічних i фізичних явищ, неорганічної матерії [5, с. 117]. У мовознавстві першим, хто на початку XX ст. спробував встановити взаємні зв'язки між фактами мови та мовленням, згрупувати їх і виявити внутрішні корелятивні відношення, синтезувати їх в єдине ціле, побудувати систему відповідних елементів і створити єдиний цілісний об'єкт дослідження, був швейцарський мовознавець Ф. де Соссюр, а його основна заслуга перед лінгвістикою XX ст. полягає в тому, що він звернув увагу на необхідність вивчення мови як цілої системи, як такої, що складається із взаємозв'язаних i взаємозумовлених елементів мовлення. Соссюр висунув важливе положення про системний характер мови та мовлення, визначив мову як систему, яка підпорядковується своєму внутрішньому ладу, як сукупність узаємозалежних елементів, пов'язаних між собою відношеннями. Важливим положенням теорії Соссюра $є$ розмежування мови й мовлення. Мова й мовлення, згідно 3 позицією Соссюра, тісно пов'язані між собою й передбачають одне одне. Мова необхідна, щоб мовлення було зрозуміле, а мовлення, своєю чергою, необхідне, щоб встановилася мова. Відтак, функціонування мови, на думку Соссюра, виявляється в мовленні, живе мовлення $є$ формою існування й розвитку мови [7, с. 67].

Заслуга Соссюра полягає в тому, що на початку XX ст. центральною проблемою мовознавства він зробив проблему цілісності мови, а суперечливі положення його широкої загальної теорії мови через 10 років стали теоретичною основою різних напрямків лінгвістичного структуралізму. Історичне коріння цього напрямку знаходимо в індійській мовознавчій традиції, у перших спробах суворого опису мови давньоіндійським ученим Паніні. У Середньовіччі цей напрямок виражається в загальній раціональній 
граматиці, пізніше - у роботах Р. Декарта та В. Лейбніца. На виникнення й формування структуралізму дуже вплинули ідеї Бодуена де Куртене, Ф. Фортунатова, Л. Блумфилда, М. Троцького, Л. Сльмслєва, Е. Сепіра. У 20-40 pp. ХХ ст. виникають школи структуралізму, які відіграли значну роль у розробці його концепцій $і$ методів: Празька лінгвістична школа, датський структуралізм (або глоссематика), дескриптивна лінгвістика в США. Помітний вплив на становлення структуралізму російської формальної школи в літературознавстві (Є. Поліванов, Л. Якубинський, Ю. Тинянов тощо) $[1$, c. 87$]$.

Багатоаспектні погляди Ф. де Соссюра на досить суттєві питання дослідження мови як соціокультурного детермінанта формування мовної особистості єднає спільна концептуальна платформа, сутність якої можна виразити такими тезами: 1) мова - це системно-структурне утворення, у якому всі його одиниці пов'язані між собою різними відношеннями; 2) мова - це система знаків, співвідносних 3 іншими символічними системами в межах спільної для них дисципліни семіотики; 3) при вивченні будь-якої природної мови варто розрізняти мову й мовлення; 4) в основі мовної системи універсальні відношення - синтагматичні й прагматичні зв'язки між одиницями мови на всіх їх рівнях; 5) мова може досліджуватися 3 двох поглядів - синхронічного й діахронічного, пріоритет при структурному вивченні мови належить синхронії; 6) статика й динаміка $є$ такими станами мови, які співіснують; за рахунок статики балансується мова як система, динаміка забезпечує можливість змін у мові; 7) мова - самостійне явище 3 власними внутрішніми законами, вивчати іiі треба передусім 3 урахуванням внутрішньомовних чинників; 8) у дослідженні мови необхідно використовувати суворі, точні методи, які зближують лінгвістику з природознавчими науками.

Практичний досвід викладання іноземної мови у вищій школі показує, що інтеграційні процеси, які пронизують сучасну Європу, створюють об'єктивні передумови для поглиблення контактів між народами, розширення горизонтів співробітництва, а відповідно й вимагають створення адекватних механізмів для діалогу культур, поглибленого розуміння народами одне одного, толерантного сприйняття відмінностей, подолання суперечностей та локальних конфліктів, що інколи виникають. 
Отже, мовні стратегії як механізми освоєння і користування іноземними мовами в багатомовному культурному просторі, їх сукупність $\epsilon$ основним культурним комунікаційним засобом, провідним елементом соціалізації особистості, іï аккультурації. Ф. де Соссюр розглядає мовні стратегії як засіб розуміння народами культурних відмінностей одне одного, осягнення цих відмінностей як унікального формовитвору єдиної людської сутності, досягнення на цій основі їх (особливостей) толерантного сприйняття. Вони розглядаються як засіб подолання непорозуміння (неадекватного розуміння), яке завжди виникає при комунікації культур у багатокультурному європейському просторі. Освоєння мовних стратегій $є$ пріоритетним напрямом освітньої політики країн-учасників Болонського процесу. Ця норма $є$ пріоритетною й для України.

\section{Література}

1. Воробйова I. А. Формування соціокультурної компетенції учнів старшої школи засобами іноземної мови : дис. ... канд. пед. наук / І. А. Воробйова. - К., 2003. - 194 с.

2. Гумбольдт В. Язык и философия культуры / В. фон Гумбольдт. - М. : Прогресс, 1985. - $586 \mathrm{c}$.

3. Коломінова О. О. Шляхи формуванння лінгвокраїнознавчої компетенції учнів початкової школи у процесі навчання англійської мови / О. О. Коломінова // Нариси досліджень у галузі гуманітарних наук у педвузі : зб. наук. та наук.-метод. праць. Горлівка : ГДПІІМ, 2002. - С. 250-252.

4. Першукова О. О. 3 історії розвитку соціокультурних аспектів вивчення іноземних мов у Європі / О. О. Першукова // Іноземні мови - 1999. - № 4. - С. 16-20.

5. Садохин А. П. Введение в теорию межкультурной коммуникации / А. П. Садохин. - М. : Высшая школа, 2005. -310 с.

6. Сафонова В. В. Социокультурный подход к обучению иностранным языкам/ В. В. Сафонова. - М. : Высшая школа, 2001. - 311 с.

7. Соссюр Ф. де. Курс общей лингвистики / [пер. А. М. Сухотина; под. ред. и с примеч. Р. И. Шор; ввод. ст. Д. Н. Введенского] / Ф. де Соссюр. - М. : Соцэкгиз, 1933. $-387 \mathrm{c}$.

8. Формування професійної культури вчителя в контексті інтеграції України в європейський освітній простір : Матеріали регіонального науково-практичного семінару за ред. проф. Терещука Г. В. - Тернопіль : Вид-во ТНПУ ім. В. Гнатюка, 2007. $-177 \mathrm{c}$.

Стаття надійшла до редакиії 31.03.2015 p. 